\title{
The Experience of \\ Guestworkers at a United \\ States Tourist Resort
}

Guilherme Mansur Dias

PPGAS/IFCH/UNICAMP

\section{Abstract}

This article examines temporary employment among foreign workers at the Okemo Mountain Resort, a tourist ski complex located in Vermont state in the north-eastern United States. I discuss the meanings associated with the international displacement of these workers, focusing especially on the ideas and imagery surrounding 'mobility', 'work,' 'travel' and 'youth.' By describing their experiences, along with the practices and discourses of the employer and the US State, the case study shows how Okemo's strategy of hiring a flexible foreign workforce is connected to the multiple meanings through which these groups represent their experience of temporary migration to the United States in the context of increasingly precarious labour relations. The ethnographic analysis proposed by the research provides a counterpoint to the 'macro-analytical' approach employed by most studies on the issue of foreign temporary work in the United States.

Keywords: International Mobility; Guestworker Program; United States of America; Migration; Youth.

\section{Resumo}

Desenvolvo neste artigo algumas reflexões sobre o significado da experiência de trabalho temporário entre trabalhadores estrangeiros no Okemo Moutain Resort, complexo turístico localizado no estado de Vermont (EUA). Faço isso a partir da discussão dos sentidos e representações associados ao deslocamento internacional desses trabalhadores, com especial ênfase a seus discursos e 
imaginários de "mobilidade", "trabalho", "viagem" e "juventude". Ao descrever suas experiências em conjunto com as práticas e representações do empregador e do Estado norte-americano, o estudo de caso revela como as estratégias do Okemo para obter uma mão-de-obra estrangeira flexível estão articuladas aos múltiplos sentidos através dos quais estes grupos representam sua experiência de migração temporária para os Estados Unidos, em um contexto de precarização das relações trabalhistas. A perspectiva etnográfica da pesquisa também estabelece um contraponto ao viés "macro-analítico" de boa parte dos estudos dedicados à problemática do trabalho temporário estrangeiro no país.

Palavras-chave: Deslocamentos Internacionais; Programas de Trabalho Temporário; Estados Unidos - Migração; Mobilidade; Juventude. 


\section{The Experience of \\ Guestworkers at a United \\ States Tourist Resort}

Guilherme Mansur Dias
PPGAS/IFCH/UNICAMP

Introduction

This article is a contribution to the debate on international labour circulation and identities through a case study of the meanings linked to the seasonal migration of temporary workers of different nationalities to the Okemo Mountain Resort, a tourist complex in the US state of Vermont. I explore some of the conceptions attributed to the travel and work experience of these workers, emphasizing how they interconnect with US policies designed to recruit foreign workforces. I do so through an ethnographic approach that focuses on the meanings attributed by the workers themselves. I aim to comprehend these meanings in conjunction with the practices and representations of their employer and the US State in relation to discussions concerning flexible labour relations in that country.

The development of this topic stems from my participation as a researcher and temporary worker at Okemo in the 2005/2006 winter season. After visiting the Resort on an earlier trip in 2004, a number of aspects awoke my curiosity, especially the distribution of job positions between foreign workers of different nationalities. This eventually led to my interest in carrying out ethnographic research to understand what seasonal migration meant to these workers. ${ }^{1}$ As a means of accessing the field site, I applied to a 'Guestworker Program' and was hired as a temporary worker for one of the posts made available to foreigners: a ski lift operator.

1 This research was undertaken as a student at the Graduate Program in Social Anthropology of Campinas State University (UNICAMP) and funded by the São Paulo State Research Support Foundation (FAPESP). The author's master's dissertation, 'Temporary Work Experiences in the United States: an ethnographic approach from Okemo,' was completed in 2007. 
During my four-month stay in Vermont, I combined my work activities with ethnographic research, developing contacts with the resort's foreign workforce. The fact that I too was working for Okemo helped considerably in terms of making these connections and establishing relations of trust with the other workers by sharing the same spaces and work routine as some of them. I also continued my research activities outside working hours, conducting interviews with foreign workers and the employer, ${ }^{2}$ and taking part in dinners, parties and meetings. Participant observation and interaction with the foreigner workers and with other sectors of the resort shaped the 'ethnographic fact' of the research (Peirano 2009: 58).

My analytic approach is rooted in an anthropological literature that problematizes the diversity of international migration, not through a simple celebration of hybridisms, mixtures and mobilities, but through the realization of historical-ethnographic studies capable of revealing the power relations and representations generated by these international labour movements. ${ }^{3}$ Supported by detailed case studies, this theoretical and analytic framework enables a heterogeneous and multiform approach to the distinct processes of migration and mobility of people in the contemporary world.

\section{A brief description of Okemo and its links to the Guestworker Programs}

Located in the town of Ludlow, Vermont, the Okemo Mountain Resort was founded in $1955 .{ }^{4}$ Its opening coincided with the development of the ski industry across the USA and with a project to generate local development through economic activities related to tourism. Starting out as a local business, Okemo has extended its reach considerably over the last few decades

2 The field research was conducted with the consent of the employer, which itself collaborated in the study via its Human Resources Department, which granted me structured interviews.

3 As inspiration for this approach, I cite the works developed in the line of research 'Nation and Diaspora' (CEMI/UNICAMP) of the project 'Identities: Reconfigurations of Culture and Politics' (see for example Caetano da Silva 2003, Feldman-Bianco 2001(a), 2001(b), Machado 1997, 2003, Silva 200o, Sanjurjo 2007, Santos 2002), as well as ethnographies published by the journal Identities - Global Studies in Culture and Power (especially Identities: Global Studies in Culture and Power, v.11, n.3, 2004).

4 This brief history of Okemo is constructed from interviews with local residents and visits to the small archives held by the public library in Ludlow (VT). 


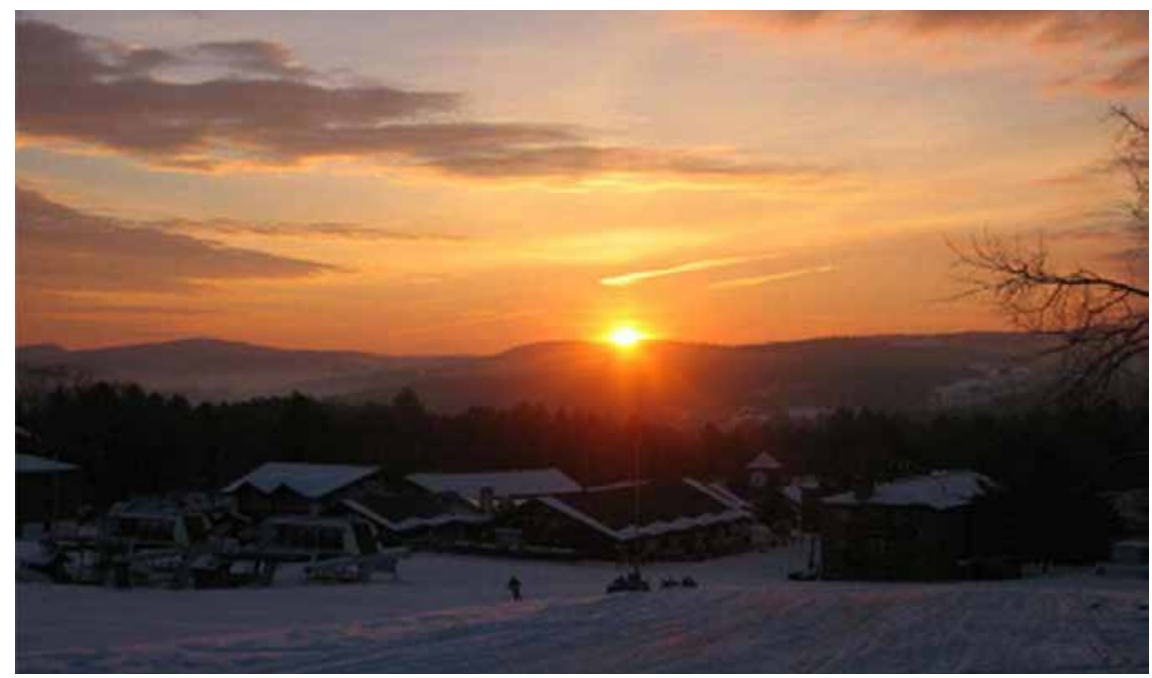

Figure 1: Okemo Mountain Resort

with the expansion of tourism-related activities in the United States and the association of Vermont with winter sports.

At the start of the 1980 os the resort was purchased by a young couple, who began to make more substantial changes. As well as improving the hotel accommodation and ski slopes, the new investors opted for a resort model then being developed in the west, basing growth on the construction of lodging properties for the winter season. The initiative proved highly successful and Okemo's profits multiplied along with the flow of skiers and tourists into the region. The town of Ludlow, where tourism had once been a secondary economic activity, was restructured and the resort began to attract a low-skilled workforce from the town itself and neighbouring areas.

Okemo's growth, in turn, coincided with increasingly precarious labour relations in the US market and the consequent expansion in temporary and seasonal jobs as well as employment contracts in numerous sectors of the country's economy. According to specialists, the generation of temporary and precarious jobs and services has been a growing trend in various parts of the US economy. ${ }^{5}$

5 See, for example, Griffith 2006, Calavita 1994 and Fantasia 2003. Kitty Calavita sketches a panorama in quantitative terms of the increase in the flexibility and precariousness of labour contracts in the United States over recent years: "In 1982, approximately one-quarter of new jobs were for part-time or temporary work; a decade later, half of all jobs filled were for such 'contingent' work (Kiborn 1993: A1). The Bureau of Labor Statistics reported that go percent of all new jobs in February 1993 were part-time” (Calavita 1994: 
Within this context of increasingly precarious labour relations, the use of Guestworker Programs- official US government programs for hiring temporary foreign workers - has been (re)considered and (re)assessed by different sectors of American society. These (re)considerations and (re)assessments, in turn, involve discourses belonging to different spheres of the State and wider society and are connected to specific representations of the role of foreigners and immigrants in the country.

One of the explanations for the apparent 'revival' in this type of program has been the idea of controlling foreigners and borders for reasons of national security, a tendency reinforced in the post-9/11 context. ${ }^{7}$ The proposal for new Guestworker Programs in the United States has emerged, therefore, as part of an argument for increased border surveillance and as a panacea for the 'problem' allegedly posed to diverse sectors of American society by undocumented immigration. Hence the recent (re)considerations of temporary work programs for foreigners in the USA are related to the promotion of State policies that simultaneously aim to fill gaps in the labour market in specific job sectors and to facilitate border control by providing 'increased security' vis-à-vis the foreigners intent on migrating to or working in the country.

Despite the current (re)consideration of Guestworker Programs in the US, backed by ideas such as increasing border controls and precariousness of labour relations, other arguments have been raised to justify such policies. One particularly influential argument has been that Temporary Work Programs in US immigration legislation are needed as a way of responding

64). For further data and discussions on the spread of temporary and precarious employment contracts in the United States and Europe, also see O. Bergstrom \& D. Storrie (2003).

6 I employ the terms (re)consideration and (re)assessment over the course of the text to reflect the fact that use of Guestworker Programs is not a new phenomenon in the United States. Although large-scale Guestworker Programs - like the Bracero Program, introduced to recruit Mexican workers for the country's plantations during the first half of the twentieth century - were cancelled in the post-war period, the use of such programs in the USA and some European countries has continued through smaller programs targeted at specific economic sectors (see Briggs 2004, Castles 1986, 2006, Martin 2003,Ruhs 2001).

7 The line of argument pursued by Stephen Castles (2006) is fairly clear on this point: "In recent years there has been a tendency to advocate a return to TMWPs (Temporary Migration Worker Programs) in democratic receiving countries. One reason is the perceived demand for migrant workers due to the economic and demographic factors [...] A second reason is the realization that border control alone will not fully prevent labor migration, but instead drives it underground. A third reason is the post-September 11, 2001, belief that undocumented migration is a security problem. If migration is going to take place anyway, politicians now think it better to control entrants to ensure that they do not pose a security threat" (Castles 2006:747). 
to international competition and enabling better penetration of the US economy at global level ${ }^{8}$.

Indeed the (re)consideration of Guestworker Programs in the USA over the last two decades also seems to be linked to this kind of 'competitive framework of the neoliberal State' and an emphasis on increasing US competitiveness at international level. This argument, in turn, is commonly associated with the demand for more liberal employment relations, which merges with the increase in precarious work contracts and the institutionalization of the temporary and flexible nature of migrant labour.

As part of this context, in 1999 Okemo began to make use of two official Guestworker Programs to recruit foreign workers: the H-2B visa program and the J-1 program for holiday workers. ${ }^{9}$ The resort's use of these programs to hire foreign workers began timidly but has expanded over recent years. To a large extent the complex's participation in the Guestworker Programs is intrinsically related to the ample incentives now given to recruiting temporary foreign labour in the country. Through these programs, Okemo today hires workers from a variety of countries and with distinct kinds of work visas who work in a range of seasonal jobs allocated according to their nationality.

In the resort, the visa programs (J-1 and $\mathrm{H}-2 \mathrm{~B})$ are related to flows of people from different countries and depend on a particular history of contacts between the human resource team and intermediary recruiting companies/ agents based in their countries of origin. Thus while the large majority of seasonally hired Australians and New Zealanders ( $\mathrm{H}-2 \mathrm{~B}$ visa) worked in the

8 On this question, Philip Martin argues that: “(...) in the 199os, there was a new wave of guest worker programs, and they differed from earlier programs justifying migrant admissions on the basis of labor shortages as well as globalization, foreign policy and other reasons. The globalization argument was heard frequently in US debates over expansion of programs that admit foreign professionals, and it runs like this: the US has five percent of the world's population, but a far higher percentage of the world's cutting-edge industries, and thus US employers need easy access to the best and brightest from around the world to stay competitive globally" (Martin 2003:08).

9 The H-2B visa program is the result of the legislative extension of the H-2 Program, an older temporary labour program for agricultural workers which has been active in the United States since the 1952 Immigration and Nationality Act. The H-2B visa is issued by the U.S. Citizenship and Immigration Services (USCIS) and receives certification from the U.S. Department of Labor that no local workforce exists to fill the job vacancies in question. The J-1 visa program, despite being directed towards 'exchange visitors,' allows the recruitment of university students as 'holiday workers' in order to work in 'low prestige' jobs in the country. This visa was introduced in 1961 through the Fullbright-Hays Act in order to promote educational and cultural exchanges between the United States and other countries around the world. It is worth emphasizing that the original guidelines and meanings associated with both visa programs have since been somewhat transformed. 
resort's 'outdoor' jobs related to ski activities, a group of young people from South America (J-1 visa) worked in jobs linked to the restaurants, cafés and crèches. A group of Jamaican workers (H-2B visa) performed the less prestigious jobs related to cleaning and catering services. ${ }^{10}$

Okemo's growth, closely tied to the context described above, led to the recruitment of these foreign workers, at the same time that it became directly based on the exploitation of their labour. This was also stimulated by the fact that the type of work contract involved was extremely convenient for the employer. Okemo in fact has to disburse very little on the bureaucratic process of recruiting these employees. Apart from the actual wages and a tax paid to the United States Citzenship and Immigration Services (USCIS) for each foreigner hired via the $\mathrm{H}-2 \mathrm{~B}$ visa, the resort offers no additional benefit to its international workers, which is in tune with its aims of rapid growth and capital accumulation.

During field research it became clear that the differences between distinct groups of workers were constructed, both for and against their own wishes, by the employer, State, recruiters and themselves. These differences were related to their national and class origins, the type of visa held, how they were recruited, their job positions and lodgings at the resort, and, above all, the representations created around their experience of living and working abroad.

In this text, I examine some of the representations linked to the labour migration of these different groups of temporary workers, showing how their distinct conceptions of 'youth,' 'work,' 'travel' and 'mobility' acquire meaning within a specific ethnographic context. The decision to focus on these analytic categories corresponds to the importance attributed to them by the research subjects themselves when they reflected on their motivations, trajectories and lifestyles. In the ensuing description, it will become clear how the interpretation of their experience in the United States is linked to the meanings attached to these categories.

In describing these meanings, contrasting them to the practices and representations of the employer and the State, I also problematize the notions of

10 This sectorization of jobs by nationality is not entirely inflexible: in some cases foreign workers may be assigned to positions not commonly associated with their national stereotype. My own field trip is an example in point. Interested in working with Australians and New Zealanders at Okemo, a group I had met on my previous trip to the Resort, I contacted the human resources department to ask to work with this group of foreigners, which was duly arranged. 


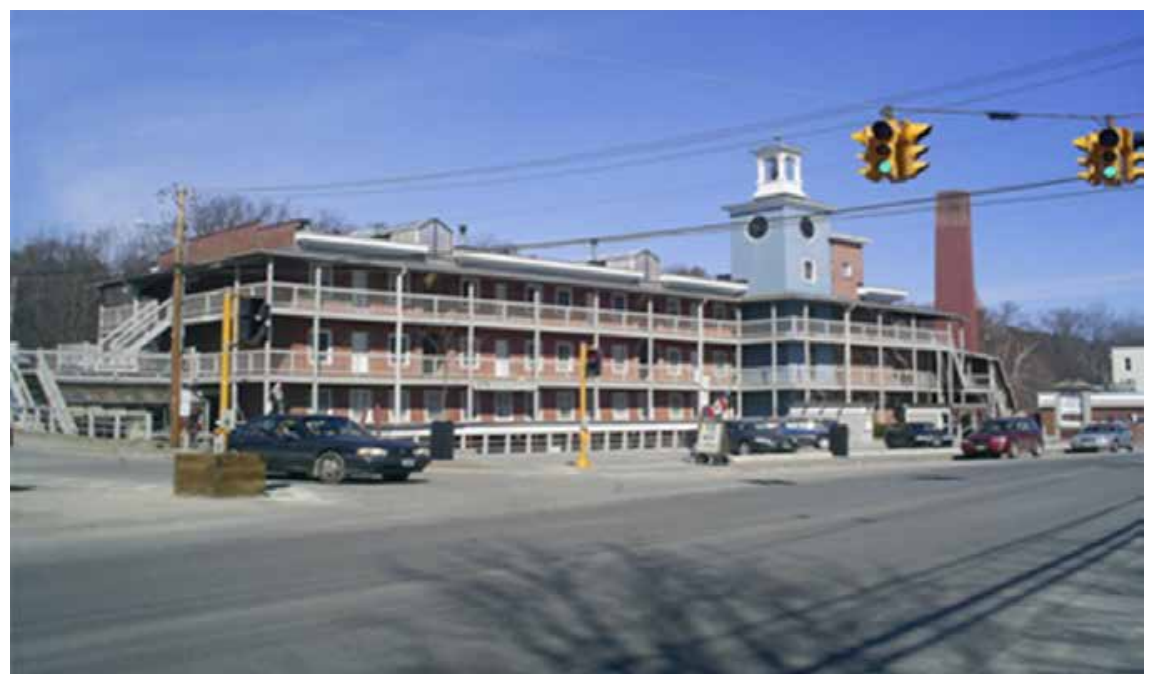

General Eletric's old plant in Ludlow (VT), the building is now used to host tourists.

'flexibility' and 'job insecurity' in the USA, showing how they acquire meaning in the lives and experiences of concrete subjects who travel to work in the country on a seasonal basis. The contrast between the symbolism associated with their experience and an academic literature that discusses temporary work through a 'macro-analytic' approach will also be discussed and reviewed at the end of the text.

\section{Australians and New Zealanders in Okemo}

The Australian and New Zealand workers recruited by Okemo for the 2005/2006 winter season travelled to Vermont having had previous work experience in ski resorts located in their home countries. Most of them came from working class backgrounds, had no university training and had been employed in 'low skill' services prior to working in similar resorts in Oceania.

Okemo recruits these workers through contacts maintained with their previous ski resort employers in Australia and New Zealand, sending representatives to persuade the youths to come to the United States to work for the ski resort ${ }^{11}$. Maintaining these people in the seasonal jobs related to winter

11 The ski resorts where those workers were previously employed in Australia are located in the states of Victoria and New South Wales, in the south-east of the country. At Okemo they were hired to fill posts such as 'ski lift operators' and 'snowmakers,' the latter responsible for maintaining the resort's snow 
sports involved a combination, therefore, of Okemo's interest in hiring foreign workers for their seasonal positions and the advantages associated to this kind of job by those young employees.

In the latter case, we can perhaps identify a degree of correspondence between their conceptions of 'youth' and the expectations that had led them to seek out the winter jobs. For these workers, this kind of job position was desirable for an intermediary period of their young adulthood and included a wish to accumulate 'new experiences'. Many of the Australians and New Zealanders working at Okemo told me that their decision to work abroad was prompted by the search for a lifestyle that would break away from 'more serious' professions or careers. In their case, these projections and stereotypes were similar to Desforges's description (2000) of the identity of young British backpackers who travel alone to southern countries in search of experiences taken to be innovative and necessary for concretizing their 'youth projects':

Youth is imagined as a period in life when new experiences are important. In later periods of one's life, according to Jenny and other young tourists' narratives, commitments to others, in the form of jobs and personal relationships mean that it is impossible to pursue new experiences through mobility. These participants felt that unless they experienced the world in their youth, they would feel a sense of lack later in their lives having missed out on the opportunity to develop a youthful identity for themselves. (Desforges 2000: 937).

The notion of 'youth' expressed by the Australians and New Zealanders at Okemo indeed incorporated the idea of this kind of identity being shaped through travel experiences. Hence their employment at the ski resort reinforced various stereotypes they themselves brought, including the idea that such work was inevitably associated with the 'adventurous spirit' of young adulthood. Likewise the opportunities and jobs found in this circuit were seen as temporary in terms of their life trajectories, with many people saying that they intended to find a more serious profession or job once they had left behind this kind of work activity. The following remark from Mary provides a good illustration of the idea of youth shared by Australians and New Zealanders:

levels, driving around with snowmobiles at night and switching on and off the water hoses positioned alongside the ski slopes. 
I know this is temporary! We do this while we're young, to enjoy the moment, meet people, travel to paradisiacal places. But it's just for a time. Afterwards we have to assume responsibilities, return to adult life...

This kind of experience of youth appears to be in direct contrast to the view from the 'adult world' and the life that these youths wished to lead after renouncing it for a few years, accentuating the provisional nature of this kind of job and lifestyle. This perception is echoed in studies conducted in ethnographic contexts similar to the Okemo Resort.

Bianchi (2000), for example, suggest the emergence of new mobilities framed within the context of tourism and labour migration in Europe. The author argues that recent changes in the European labour market have created the context within which heterogeneous collections of mobile resort workers have emerged, which transcend the dualistic division between work and tourism in the course of their movements throughout a number of tourism destination areas. Based on ethnography with a group who he calls 'migrant-tourist workers' - young Britons and Germans who travel to work in seasonal jobs in the big resorts of the southeast of Europe -, he argues that the search for jobs in European resorts is a way for youths to avoid devalued jobs in countries where economic production has undergone significant restructuring, looking instead to (re)insert themselves in these new contexts:

In this respect it can be argued that they are an outcome of the declining centrality of one's occupation as a social category and locus of identity on the one hand, and a liberation from the drudgeries of work (and unemployment) associated with their 'home' societies on the other. (Bianchi 2000: 122)

Likewise the meanings attributed by the Australians and New Zealanders working at Okemo were informed by specific discourses and practices related to contemporary ideas of tourism and globalization, which associate travel experiences with sources of personal improvement and development (see Bianchi 2000,Desforges 2000,Munt 1994). Hence as well as the constant association of 'lifestyle' and 'youth' in their dialogues, these travel and work experiences were taken as opportunities to obtain personal qualifications 
associated with notions of 'flexibility,' 'learning' and 'maturing. ${ }^{12}$ Harry's account provides an insight into some of these aspects:

I think this experience is important on our return. In Australia [...] there's this thing, people want to travel and see what the rest of the world is like and, once done, there's a sense of mission accomplished. It is not indispensable, but it is important. So even if I die in the town where I was born, at least I had a look at the rest of the world. I think most people respect you more and respect your effort and decision. Even if it doesn't work out, people will say that at least you tried and took the risk. I think that's good!13

Identifying travel as a mark of distinction between specific individuals and social groups is nothing new. In a variety of different contexts and periods, travelling has been synonymous with social distinction, used as a way to obtain local power and prestige (see Adler 1985, Machado 1997, Ribeiro 1997). For the Australians and New Zealanders at Okemo, however, the trip seemed to be apprehended as a kind of 'challenge' indelibly incorporated in their life histories. Travelling to work in a different country was seen as a way of learning and achieving distinction at the same time.

In the case of these workers, their concepts of 'youth,' 'work' and 'travel' were in some ways interconnected and related to wider representations of their travel experiences in the United States. This is perhaps why the Australians and New Zealanders at Okemo have a very particular identification with this kind of work activity. Indeed rather than being seen as something disagreeable or a necessary evil, activities like working in the cold and holding chairs for skiers were seen to be 'attractive,' in contrast to some of

12 Other authors have emphasized the proximity between contemporary experiences of travel and the development of the personal traits of travellers and tourists. Munt (1994), for example, writes that some experiences of tourism nowadays "have begun to be conceived (especially among the new petit bourgeoisie) as embodying personal qualities in the individual, such as strength of character, adaptability, sensitivity or even 'worldliness"' (Munt 1994: 109).

13 Here I cannot resist a critical comparison between Harry's dialogue and the commentary made by Lévi-Strauss in Tristes Tropiques (1996) concerning explorers and travellers in the second half of the twentieth century: "Exploration has become a profession; not, as one might suppose, that it's a matter of unearthing new facts in the course of several years' laborious study - not at all! Mere mileage is the thing; and anyone who has been far enough, and collected the right number of pictures (still or moving, but for preference in colour), will be able to lecture to packed houses for several days running. Platitudes take shape as revelations once the audience is assured that the speaker has sanctified them by travelling to the other side of the globe" (Lévi-Strauss 1961:18). 
the jobs in which people had been employed before working in these winter resorts. Andrew's comments reveal the centrality of this work experience in ski resorts and his personal rapport with this type of profession:

I really like this kind of work, working outside. The wind blowing in your face, feeling nature. Though you earn more in office jobs, here it is more attractive. It's heavy, physical work. But you feel well arriving home at night and knowing you beat the cold and the drawbacks. And helped get everything here up and running!

The attractiveness of the physical aspects of this type of work was constantly contrasted with the sedentary nature of the office or factory jobs in which many had been employed before working in ski resorts. For some working in the snow meant a positive interaction with the cold and the physical reality of these jobs located in isolated mountains and remote places. As Bianchi (2000: 124) describes in relation to groups of European 'migrant-workers,' the work seems to be experienced not as an unpleasant necessity or a necessary prerequisite to accessing other experiences connected to leisure or tourism, but as an important activity in itself, comprising precisely the kind of experience desired. ${ }^{14}$

Here it is worth emphasizing that the outdoor jobs at the Okemo Resort were often exhausting due to the cold, the employer's demands and the heavy and repetitive physical work required. On weekends and holidays the day began at six in the morning and ended at five in the afternoon. Lunch break lasted half an hour at most and depended on the number of tourists staying at the resort, as well as the number of employees, which was usually relatively low, meaning that the foreign staff were often overworked. In addition the outdoor jobs were doubly exhausting since the arduous physical activities were exacerbated by exposure to the harsh climatic conditions and the thermal shocks experienced when moving between hot and cold environments.

Even so, many Australians and New Zealanders did not appear to mind performing these activities since they allowed them closer contact with the routine of the resort's ski slopes and other tourist attractions.

14 According to Bianchi “whereas work was an 'unpleasant necessity' for Cohen's drifters, it is central to the experience of migrant tourist-workers not merely to facilitate onward travel, but as something which is fulfilling in itself. Thus the balance is shifted away from the hippie mythology of drifting, to something much more purposive and calculating" (Bianchi 2000: 124). 
Okemo's recruitment strategy in Australia and New Zealand, for its part, seems to make fairly effective use of the distinct imagery connected to precisely the kind of experience sought by young Australians and New Zealanders. The recruitment talks given by Okemo in Australia and New Zealand highlighted the conditions that would enable the youths to carry on practicing the sport they liked, but with the chance of doing so while also discovering another country. Pursuing this approach, the resort was able to obtain an eager workforce with at least one season of work experience in these jobs and a surprising desire to work in the kind of employment rejected by local Americans. ${ }^{15}$

It is also worth noting that only the consular fees relating to the $\mathrm{H}-2 \mathrm{~B}$ visa issued to the Australian and New Zealand recruits were paid by the Okemo Resort: all other travel expenses had to be met by the employees themselves, who also paid a proportionally high rate for renting their accommodation. ${ }^{16}$ These workers were, therefore, more attractive to the employer than the local workforce due precisely to the identification of the young people with the activities that they performed and their previous work experience in ski resorts in their home countries, as well as the extremely flexible labour relations and the greater likelihood that they would maintain a subordinate relationship to the employer.

In terms of the this issue, it is worth recalling here that the $\mathrm{H}-2 \mathrm{~B}$ visa issued to the Australian and New Zealand workers afforded the employer effective control over the temporary worker's status, since the former simultaneously became the latter's sponsor for the period of his or her stay in the country. This type of labour relation has already been identified as a potential source of problems in various other studies and contexts (Ruhs 2002, Griffith $1986,2006)$. The visa's direct link to the guestworker's job can force him or her to accept and be subjected to harsh working conditions.

15 Here I refer to those American residents living in the area around the town of Ludlow who could feasibly have been employed by Okemo. Because of the low wages paid by the resort, though, many positions were actually filled by workers from other countries.

16 The employees paid around US $\$ 2500$ for the return air fare and US $\$ 400$ per month in rent for lodgings. Given that the Okemo Resort paid around US $\$ 1200$ per month in wages - equivalent to seven or eight dollars per hour - it is very difficult to understand the procurement of this kind of job as a simple work alternative or a form of immigration. It was the desire to practice winter sports and the conceptions related to travel that, in fact, propelled these youths into the US labour market. Aware of how to capture their interest, the resort's Human Resources department was able to achieve a fairly satisfactory solution to recruiting an attractive workforce. 
Although some youths incorporated the positive discourses related to their work trip, therefore, the limitations of the temporary work program with a $\mathrm{H}-2 \mathrm{~B}$ visa surfaced whenever the employer made heavier demands or gave them too many responsibilities. Andrew and Harry, for example, recalled how, at the end of the season, they had worked far harder than they had anticipated, and how they had received no help and insufficient leisure time to engage in the other activities they had planned, leaving them somewhat disappointed with the trip. Both remarked that they had hurt their backs during the work due to the excess tasks and the lack of work companions or help on the ski lifts. Narrating how he had injured himself, Harry described a confrontation with his immediate supervisor and the latter's harsh response:

One day I was working alone and hurt my back [...]David [his supervisor] then said that they had never had workers as weak as us. I replied that if they continued to assign just one person to the ski lift for the whole day, that was what was going to happen. I went and paid for a massage with my own money. I wouldn't otherwise go for a massage, I only went because I was in pain. It was no fun, it hurt a lot [...] I think they didn't like the fact, it seemed that I was being...that I was being... weak because I had injured my back...and they talk and intimidate you to make you work harder. Even today my back hurts and I am still injured[...]And I work as hard as I can... and they do this because there is no one else [...] and because we are foreigners, it's easier to threaten us!

Hence despite the apparently 'positive' connotation of the work performed by these young adults and the meanings attributed to their work trip, many faced instances of exploitation or situations at the resort that exposed their status as foreign workers in the United States. Even so, these contradictions did not annul the association of the previously listed aspects with their experience of work and travel. While some events or working conditions cast a cloud over a 'positive' approach to their seasonal job, the 'experience' that they desired seemed to be correspond fully enough to the winter sports jobs they sought, the stereotypes of youth they looked to emulate, and the views of travel they shared.

Okemo's strategies for recruiting these workers were, for their part, related to the perspectives and plans cultivated by the youths based on their Australian and/or New Zealand context. By offering the chance for a particular kind of 'experience' in a foreign land, the recruiters managed to capture 
the diffuse interests of these young people, allowing them to appeal to a highly attractive profile of worker. Hence the representations of the employer, temporary workers and State very often intersected, such that the meanings associated with 'youth,' 'work' and 'mobility' were mixed up with the everyday life of the resort. These conceptions converged, therefore, to shape the flexibility encountered at Okemo.

\section{Travel as Personal Investment: the Experience of South Americans at Okemo}

The South Americans who travel to the US to work at the Okemo Resort arrive via a temporary work program known as 'Work Experience' or 'Work and Travel' targeted at university students from nations with which the USA maintains diplomatic relations. The program is run through public and private companies and agents working in the United States and the countries in question and the applicants enter the USA via the J-1 visa, the central aim of which, according to the definition on the official webpage of the US State Department, is to "encourage mutual understanding between American citizens and those of other countries through 'cultural exchange programs'."

The J-1 visa program was created by the United States in 1961 and is fairly wide-ranging, encompassing 'Work and Travel' as one of several exchange programs designed to foster these forms of "mutual understanding between American citizens and those of other countries." The 1961 legislation is consistent with the broader discourse created in the USA during the Cold War with the aim of disseminating a 'pacifist' ideal via 'cultural exchange' experiences between citizens of countries ideologically allied with the United States and Western Europe. It is through this kind of argument, therefore, that the 'Work and Travel' programs have been justified by the US State Department.

Through these incentives, university students from different parts of the world travel to work in 'low-skilled' jobs in the US labour market. In Okemo's 2005/06 season, this contingent was represented by a group of Chileans hired to work in jobs linked to the restaurants and bars, as well as Colombian and Argentinean women responsible for looking after the children in the resort's crèche.

The 'Work and Travel' J-1 visa program, notwithstanding all the State propaganda on the etiquette of 'cultural exchange,' effectively acts as a 
bridge between employers from the US service industry and young university students from South America, reconciling the interests of both sides: the employer's interest in recruiting an attractive, relatively low-cost workforce, and the students' interest in travelling abroad and gaining the kind of 'international experience' offered by the program.

One recurrent feature of the dialogues and motivations of the South Americans working at Okemo is that the trip seemed to be effectively meaningful in terms of their local lives and contexts, producing experiences deemed "necessary in today's world. "Its connotation, however, went beyond the notion of 'cultural exchange' promoted by the US State and was closer to a more specific idea of 'investment'. Hence their 'travel abroad' was perceived more as a form of 'personal promotion' grounded in apparently tangible future gains rather than any possibility of 'cultural exchange.'

In his doctoral thesis, Osvaldo López-Ruiz (2004) argues that the formulations and innovations in economic science made by the Chicago School in the 1960s - notably by the 'theory of human capital' - led to the diffusion of a new set of values concerning the individual and the 'human,' which assumed a crucial importance in defining the ethos through which many subjects, in different social contexts, interpret their lives. López-Ruiz goes on to suggest that the 'economic' ideas developed by the Chicago School and which encompass the conception of individuals as business enterprises, the bearers of skills and capacities that are incorporated and valued as 'investment' - have now become widespread. Investment, in this case, over and above its role as a key economic term, has been transformed, the author argues, into a notion that likens human existence to the management of a personal enterprise. ${ }^{17}$

For López-Ruiz, the widespread change provoked by the 'theory of human capital' resides in the profound inversion of values caused by replacing the notion of 'consumption' with the notion of 'investment.' In the process work becomes theoretically comprehended not only as a factor in production but as 'the product of an investment,' implying that the worker's abilities, knowledge and skills are also to be seen as an object of management. The biggest change, in this case, is that the theory precipitated a moral inversion

17 According to the author, this theory, formulated to solve strictly economic problems, had extended its explanatory reach to other social dimensions, simultaneously explaining and proposing a new model of personhood, a subject capable of thinking of him or herself explicitly as capital (see López-Ruiz 2004). 
that allows subjective and personal attitudes, actions and characteristics to become freely conceived and perceived to be open to valuation.

In the case of the present study, the shift from conceiving this type of working trip as 'hedonistic' (leisure) or 'educational-pacifist' (the US State's original legislative framework for cultural exchanges) to conceiving it as 'pragmatic-rational' converges with López-Ruiz's sociological analysis insofar as it shows that, for some groups, the exposure to certain premises and concepts linked to contemporary capitalism transforms complex decisions - such as those involved in working temporarily in another country - into an opportunity to maximize personal benefits.

What makes the symbolic meanings associated with the temporary work of these young Latin Americans at Okemo so particular, though, is the fact that this pragmatic perception of the work trip is sustained through the idea - not always explicit - of 'personal investment,' an idea amalgamating their specific projections and perceptions of 'future' and 'youth.' This can be observed in the following remarks by Samira, a Colombian woman from Bogotá, who considered this kind of travel indispensable to achieving a good job placement on the labour market in her own country:

My course [modern languages] is directly linked to business. We learn the most important business languages and generally work for transnational companies [...] the most important aspect of this trip, however, is the experience. Because for me what matters most is the contact with people from other places, this multicultural contact $[. .$.$] This is highly valued by companies today and it is$ what this kind of trip provides...

In the case of the Colombian woman, the experience of 'multicultural contact' seems to be an important form of currency and a sign of investment in a wider set of requirements "valued by companies today". What "this kind of trip provides" is, she suggests, direct access to better employment opportunities. From time to time, this interpretation was combined with another recurrent theme of the Latin American workers at Okemo namely learning and improving their English - to suggest that this kind of trip was not entirely disconnected from the pragmatic interest of the stay. Carolina, another Colombian woman who applied to the J-1 visa program after a friend's recommendation, recounted how she had decided to pursue the venture: 
I first thought about taking part in the program when Pablo, my classmate, came back and said that it was an excellent program. But I had not thought of participating until then. Because I did not want to work in a job beneath my studies. But then I remember him telling me that coming here would be a great chance to improve my English. I would be able to experience everyday American life, live like they live [...] So I decided that I wanted to go, but I wanted to go to the north, to stay somewhere far away from the Latinos [...] And I knew that in the north there were fewer Latinos and I could force myself to speak more English. So I told the recruiter that I wanted to come to the north and this is where I ended up!

Carolina's explanation mixes precisely the pragmatic need to improve her English with a stance fairly typical of her class status in her country of origin, enabling access to university and a slightly more advantageous position in the labour market: "working in a job beneath her studies" seems valid only if she can stay somewhere "far away from the Latinos" and learn English. The equation 'language' = 'status' = 'social position' means that her aversion to working in a devalued job (-) can be set aside in order to improve English (+), since this improvement may lead to an 'upgrade' in her later social position (+).

This view point helps us understand the fact that the representations of the young South Americans at Okemo concerning their experience of travel and work in the United States seemed most of the time to be positive. The meaning given to their incorporation in the US labour market also seems to be consistent with a series of changes in meaning perceptible in the ideologies associated with contemporary globalization. Hence, for example, just as the more precarious labour relations to which they were subjected in the USA were treated as 'flexibility' (a positive characteristic), so 'seasonal migration' was transformed into a 'work trip' and the young people incorporated in these flows tended to perceive themselves to be accumulating life experiences that, rather than being an exploration of their work, were an important part of their professional 'future.'

This 'panglossian' reading of the experience of temporary work in the United States was not uniformly shared, though. For some the 'Work and Travel' program was the first step in establishing a more long-term work stay abroad. It was not uncommon for program participants to try or wish to obtain other jobs after the first work trip. Many tried to find other 
opportunities for staying and living abroad after participating in 'Work Experience. ${ }^{18}$ Using participation in the program as a source of certification, some searched for better professional opportunities, including in other countries.

The combination of future plans, desires and life projects seemed, then, intrinsically linked to the interpretation that these young people gave to their trip to the United States. Despite being subjected to the forms of coercion inherent to the world of work, many preferred to see the situation as a 'challenge' to be overcome or a unique opportunity for them to 'enjoy life,' while reconciling the experience with their professional plans.

Although the distribution of job positions at the Okemo Resort is to some extent associated to the meanings through which those different groups represent their experience of temporary migration to the US, this distribution is also related to the employer's stereotypes about their nationalities. In the case of the young South American workforce, the university students had access to indoor temporary jobs and those related to child care, usually working as waiters, shop attendants or crèche staff looking after the children of the skiers. The distribution of jobs between those workers took into account their education background and their desire to interact directly with the American public, but also represents the perspective of this North American employer to somehow associate South Americans with food and care ${ }^{19}$.

The way some job positions were 'naturally' associated with specific national groups of temporary workers becomes clearer when we contrast the experiences of young Australians, New Zealanders and South Americans with those of the Jamaican workers. Although the latter were much more familiar with the English language, they performed less 'visible' jobs at the resort involving limited contacts with the public, such as cleaning the

18 There was even the case of a South American worker who used the program as a strategy to migrate and remain in the United States. As he had tried twice, unsuccessfully, to obtain a tourist visa in his home country, he decided to apply to the Guestworker Program, making it easier to enter the USA. After the season working at the resort, he went to stay with family members in Texas.

19 I appreciate the comments provided by Peter Fry to this paper, in particular those linking the employer's stereotypes with the job distribution at Okemo. While young people coming from Australia and New Zealand were offered jobs outside, providing safety for the guests and ski practitioners (Australia = fresh air, safety), South American employees were assigned to indoor jobs, taking care of food and babysitting tourist's children (South America = food, care). 
washrooms, working in the kitchens or housekeeping. The distribution of this kind of work to the Jamaicans was a satisfactory solution since there seemed to be certain reluctance to assign the more 'undesirable' jobs to the South American university students. Although all the positions offered to foreign workers at Okemo were 'low-skilled,' there were always some that were lower, as I describe further.

\section{A Permanent Temporary Work Program: the Jamaicans at Okemo}

The contingent of Jamaican workers seasonally hired by Okemo have a quite different profile to the young people presented so far. They involve a group of slightly older people, mostly aged between thirty and fifty years old, who worked in indoor jobs at the resort related to cleaning and catering services. These workers, recruited through the $\mathrm{H}-2 \mathrm{~B}$ visa program, did not have university education and came from a working class background linked to the tourist industry in Jamaica. Coming mostly from 'resort' areas and having already worked in tourist sector jobs in the country, many used the Temporary Work Program as a form of employment contactor a regular prolongation of their work stayin the United States.

In the case of the Jamaicans, there was no link between their work trip and the 'consumption' of images and products associated with the ski resort, much less any association between the search for these jobs and the concomitant search for 'personal growth' and/or 'multicultural contacts'. They were at the resort, they would say, because of the opportunities for seasonal work and as a way of continuing with the kind of work they had performed in Jamaica but with much more attractive financial rewards.

Leaving Jamaica offered the chance for their work to be more highly valued and for them to earn more. With a longer history of work at the resort, some of them also applied for the H-2B visa to work at other tourist complexes in the United States during the summer. Consequently some of the Jamaican workers who were at Okemo during the 2005/06 winter season also returned to work in resorts and hotels during the summer.

These workers were hired via a single Jamaican agent, responsible for bringing them to the USA and assigning them to the job positions required by the resort. According to Okemo's HR manager, the relationship with this agent had first been established in 1999 when some members of the HR 
department learnt that there were Jamaicans working in other places in the town of Ludlow and that they had been hired through this person:

We heard about a breakfast bar in the town centre, we became interested and talked to them about the program. They subsequently put us in touch with the recruiter.

The recruitment of the Jamaican staff occurred, therefore, through recommendations and pre-established relationship networks in Jamaica. Many of the novice workers who came to Okemo in the 2005/06 season had already taken part in the temporary work program during the summer and were hired, they said, because of the similarity of the jobs to others they had filled working for other employers in the US previously. Other workers had been recommended by third parties who had already participated in the program for some time.

Dorothy, for example, was taking part for the first time that year. The mother of seven children, she said that the person to have recommended her was the head cook with whom she had worked at a hotel in Montego Bay. At the end of the season, Dorothy thought about prolonging her stay - looking for another employer in the summer - but said that she intended to return to Jamaica first to nominate her two children to the recruiter one of whom had taken up her previous job during the time she had spent working in the United States.

Although Okemo uses a variety of strategies to hire its temporary workers, therefore, its range of foreign workforce options also stems from the history of relations between the nations sending and receiving these kinds of migrant workers. In the case of Jamaica, the tradition of supplying a workforce to Britain, the former colonial power, and in particular to the United States is well established. ${ }^{20}$ The various bilateral agreements established between the United States and the countries of the 'British West Indies' make

20 Various works discuss the interaction between the Caribbean island and the United States. Sidney Mintz (1996), for example, pointed out that labour migration, slavery, colonialism and the plantation economy were collectively responsible for a violent and precocious exposure of Caribbean people to the ills of capitalism and modernity. For Basch et al. (1994), the dynamic of migration and mobility in the Caribbean Islands is fundamental to understanding some of the more central aspects of the social relations constituted in the islands. Examining the subject of Jamaican migration to the United States, Grasmuck \& Pessar (1991) argue that since 1840 the Caribbean country has been at the frontline of 'official' migratory processes to the north of the country. 
explicit this historical connection involving the recruitment of Jamaican temporary workers (see Griffith 2006: 139). In 2006, around a sixth of the approximately $66,000 \mathrm{H}-2 \mathrm{~B}$ visas issued to temporary foreign workers by the US Immigration Department were received by residents of Jamaica. ${ }^{21}$

Using networks officially recognized by this type of bilateral agreement, the resort annually hires a group of around one hundred Jamaican workers for its Housekeeping and Culinary Services departments. Okemo also pays for the costs involved in the expedition of the $\mathrm{H}-2 \mathrm{~B}$ visa and the workers pay for the recruitment services and consular fees. In contrast to the other groups, the air ticket is paid in advance by the resort and deducted fortnightly from the pay cheques of the Jamaican staff. According to the Okemo human resources manager, this measure was agreed between the resort and the agent, looking to facilitate and guarantee the arrival of the Jamaicans. The agreement to pay Okemo for the ticket in instalments in turn implies the worker's loyalty and connection with the employer until the end of his or her stay in the United States, a fact also reflected in their accounts.

In the case of this group of Jamaican workers, therefore, the recruitment networks indicate a more direct and continuous relationship with the resort. As well as being understood that the contract lasted until the end of the season, many of the Jamaicans intended to return to the same jobs the following year, meaning that the trip was primarily conceived as an opportunity for an employment contact and official permission to stay and work in the United States. As the wages offered by the resort were relatively high compared to the opportunities and incomes in their home country, the Jamaicans - most of them mothers and fathers of children- said that they had come to the resort motivated by the job opportunities and the chance to 'earn in dollars.'

Other experiences and motives were also cited to justify this temporary job in the north of the country, but their explanations for the trip mostly emphasized the chance to sustain their families in Jamaica or 'improve their life' through the seasonal work. Dorothy -who left her younger children with her older daughters and husband, the latter working on a highway construction project in Jamaica -recounted some of the reasons leading her to participate in the Temporary Work Program in the USA:

21 See http://www.workpermit.com/news/2006_04_20/us/resorts_need_short_term_workers.htm. Consulted 20/04/2006. 
The main reason why I came is that I need money to do things in Jamaica. My husband has to finish reforming our house. And [I have to] pay my bills and the children [two younger children] are in their last year at school, and there's also my granddaughter [...] And when you work in Jamaica, what you earn isn't enough to pay for all this. You really do have to come to the United States because the money here is stronger than our Jamaican money. So if I work two weeks here, I receive my salary and I can do a load of things in Jamaica. There you have to work and work to get things done. And I cannot save as much I can now I've come to the USA.

Embedded in the perception of the meaning of Dorothy's trip is the need to support a network of family members in Jamaica by sending back money. Previously employed in the Jamaican tourist industry, coming to the United States seemed a good opportunity for her personally and for her family. This is why Dorothy embarked for the USA, leaving her family behind.22

One of the central points emphasized by the academic literature on the Guestworker Programs in the United States is precisely the creation of a form of dependency between these program and the foreign workers taking part in them. They point out the prolongation of the participants' 'temporary' stay and their lack of citizenship rights or the chance to regularize their migratory status. ${ }^{23}$

Indeed the 'seasonality' of this type of employment can be questioned. Some of the Jamaicans whom I met in Vermont had already taken part in the same kind of Guestworker Program for over ten years, alternating the summer and winter seasons between Jamaica and the United States or even

22 Dorothy's husband worked as a road paver on a new highway in Montego Bay. At the end of our stay in Ludlow, she became very worried because the coach taking the workers to the site crashed and he was seriously injured. One of her daughters told her mother that she was anxiously awaiting her return to Jamaica after she had been forced to take care of the children and her injured father.

23 Here a critical appraisal of this bibliography is in order. The 'dependency' generated between the foreign workers and the Guestworker Programs is often discussed from the viewpoint of the 'invasion' suffered by American society and is seldom apprehended in terms of the ideas that the workers themselves have of their more or less prolonged stay on foreign soil. This kind of approach can be found, for instance, in the works of Briggs $(1986,2004)$ and Martin $(1998,2001)$. The concern over the 'illegal prolongation' of their stay in the USA appears in texts both in favour and against the implantation of the Guestworker Programs. Reubens (1986), for example, wishing to demonstrate the supposed benefits generated by such programs, argues that their use has the advantage of diluting the flows of undocumented workers into the country. In a way this argument is no different to those condemning such programs, since it is made from the viewpoint of the State and the preoccupation with the 'illegal prolongation' of the stay of foreign workers, rarely taking into account their own perceptions of their experience in the United States. 
prolonging their stay in the latter country for up to eleven months each year. Ironically, therefore, the same program also seen as temporary by the young people described earlier, figures as a more or less permanent life alternative for these other colleagues from Central America, even though, from the viewpoint of the State and their own representations, it is no more than a provisional situation, a status that does not guarantee any rights to citizenship.

The perpetuation of this group of workers in the US labour market reflects their greater dependency on the Temporary Work Programs and the absence of more attractive opportunities within the Jamaican labour market. As they were more dependent on this kind of employment contract, the Jamaicans ended up establishing a more vulnerable and subordinate relationship with the recruiter. Dorothy, for example, said how important it was to work hard at the Okemo resort, putting in a lot effort so the agent would ask her to take part in the program again another season.

The work routine and the financial gains obtained from their employment contract were read as the main reasons for their trip abroad and their experience narrated as a form of personal 'sacrifice.' This can be perceived in the distinct complaints of the Jamaicans in relation to the price of the rent charged for their temporary accommodation. Setting aside the fact that the price really did fail to match the limited comfort offered by their dwellings, this preoccupation in itself demonstrated the need they felt to accumulate more money to send back to Jamaica. This point was so important that the Jamaicans had special meetings with the resort administration to discuss the matter. However they were unable to obtain the desired changes. Discussing this topic, Patrick remarked:

Price of the house. This is an important issue. They are killing us with this. And they even continue to say that the price of the house is cheap. But I'll tell you something, they could build another of these houses at the end of the season with the money they get out of us. And they continue to say that they make no money from us. It's a lie! Everyone here comes to work on time. Everyone gives their best. Nobody calls in sick. Some days I wake up and don't want to work. Even so I go. I know that I'm doing voluntary work and I still go. I call this voluntary work!

Patrick's dissatisfaction frequently concerned the withholding of part of their earnings by Okemo's Human Resources sector as expenses relating to 
transport and accommodation. ${ }^{24}$ Doing 'voluntary work,' in this case, meant having to work for much of the time to pay for the trip and stay in an expensive place with few affordable housing alternatives. What these accounts suggest, in this case, is a fundamental difference between the meanings of this kind of experience for the Jamaicans compared to the Australians, New Zealanders and South Americans. In their case, the experience of travelling via the Guestworker Program with a H-2B visa was much closer to a sense of experience related to labour migration. The contrast between these distinct experiences and Okemo's respective strategies for obtaining a flexible foreign workforce leads us to some additional and final considerations.

\section{Temporary Work Programs for Foreigners: Contributions from an Ethnographic Perspective}

In a world involving intense human mobility, the representations surrounding very different travel experiences are inevitably ample and diverse. In the case study presented here, seasonal migration to a ski resort in the United States is understood in entirely distinct ways by the three groups. While the Australians and New Zealanders associated their experience with specific conceptions of 'youth,' interpreting their work as a kind of 'roaming' and the pursuit of a particular lifestyle, for the South Americans the seasonal work experience meant a simultaneous search for 'experience' and 'qualifications,' reinforcing a constant concern with the future and their later professional placement. The Jamaicans, for their part, travelled with much more of a sense of personal sacrifice, despite also expressing plans for the future and the desire for a better life in Jamaica.

The Okemo Resort is embedded in a context of more flexible labour relations in the United States and provides an example of the considerable leeway granted today to employers capable of recruiting their workforce in different countries through distinct visa programs offered both by the Department of Labour ( $\mathrm{H}-2 \mathrm{~B}$ visa) and by the Department of State (J-1 visa). The resort's rapid growth over the last decade has taken place in the context of increasingly

24 It should be emphasized that the resort's actions are not illegal. Unlike the H-2A visa, the granting of the $\mathrm{H}-2 \mathrm{~B}$ visa to American employers does not require them to provide their employees with transport and accommodation. However the amount paid for these items by some of the Jamaican staff corresponds to a significant proportion of their earnings. 
precarious labour relations in the country and the strengthening of the ideas of selective and circular migration. Nonetheless, the success in recruiting different groups of foreign workers also stems from the manipulation of 'local wishes' and the reinforcing of particular stereotypes associated to their countries/regions of origin.

In that sense, the temporary jobs at Okemo were allocated through various forms of hierarchies that represent somewhat how this North American resort classify those temporary foreign workers from different countries, colour, class and educational background. While white young people coming from specific British Commonwealth countries were offered jobs outside, providing safety for the guests and ski practitioners, South American employees were assigned to indoor jobs, taking care of food and drinks for tourist and looking after their children. On the other hand, black Jamaicans performed less 'visible' and prestigious jobs at the resort with limited interaction with tourists and other temporary workers. Those hierarchies, in turn, were aligned with the role of the State in classifying the profile of guestworkers through different visa programs.

At the same time, the case study shows how important it is when writing about phenomena related to human migration to avoid dissociating these processes from 'local knowledge' and particular conceptions but, on the contrary, to explore these bodies of knowledge and conceptions as the basis for comprehending migratory phenomena in more detail. We have seen that the meanings attributed by Okemo's temporary workers to their seasonal migration depend on a series of conceptions, projects and values connected to their home context and to specific understanding of personhood, life and the future. The representation of labour activities in terms of concepts like 'experience,' 'flexibility' and 'investment,' for instance, are related to ideologies central to the contemporary world, though these ideologies are always (re)evaluated by subjects with diverse interests and trajectories coming from particular social contexts.

In reflecting on the question of foreign temporary work, therefore, it is essential that we consider the perspectives of those who take the decision to work temporarily in a particular country. The 'mega-conceptual'25

25 Here I allude to the following assertion by Clifford Geertz (1973: 23) on the 'mega-conceptual' discussions engaged in by the social sciences: "It is with the kind of material produced by long-term, mainly (though not exclusively) qualitative, highly participative, and almost obsessively fine comb field 
discussions surrounding the theme -precisely the approach more usually adopted -insist on reducing the rich and diverse experiences of these groups and individuals to the view of the economy and the State. Approaching the different symbolisms and perspectives relating to foreigners who work seasonally in a US ski resort is intended to serve as a counterpoint to this 'mega-conceptual' approach.

Translated by David Rodgers

Original Language: Portuguese

Received: 20/03/2012

Approved: 24/06/2013

\section{Bibliography}

ADLER, Judith. 1985. "Youth on the road - reflections on the history of tramping". Annals of Tourism Research, 12: 335-354.

BASCH, L., SHILLER, N.G. \& BLANC, C.S. 1997. Nations unbound: transnational projects,postcolonial predicaments, and deterritorialized identities. London: Heinemann Educational.

BERGSTROM, O. \& STORRIE, D. 2003. Contingent employment in Europe and the United States. Cheltenham, UK: Edward Elgar Publishing.

BIANCHI, Raoul V. 2000. "Migrant tourist-workers: exploring the 'contact zones' of post-industrial tourism". Current Issues in Tourism, 3(2): 107-137.

BRIGGS Jr., Vernon M. 1986. “The 'Albatross' of immigration reform: temporary worker policy in the United States". International Migration Review, 20(4): 995-1019. Special Issue: Temporary Worker Programs: mechanisms, conditions, consequences.

BRIGGS Jr., Vernon M. 2004. "Guestworker programs - lessons from the past and warnings for the Future". Backgrounder:Journal of the Center for Immigration Studies, 01-07.

CAETANO da SILVA, Eduardo. 2003. Visões da diáspora portuguesa: dinâmicas identitárias e dilemas políticos entre os portugueses e luso-descendentes de

study in confined contexts that the mega-concepts with which contemporary social science is afflicted legitimacy, modernization, integration, conflict, charisma, structure ... meaning - can be given the sort of sensible actuality that makes it possible to think not only realistically and concretely about them, but, what is more important, creatively and imaginatively with them." 
São Paulo. Dissertação de Mestrado em Antropologia Social,PPGAS, Universidade Estadual de Campinas - Campinas.

CALAVITA, Kitty. 1992. Inside the state: the bracero program, immigration and the I.N.S. New York: Routledge.

CALAVITA, Kitty. 1994. "U.S. immigration and policy responses: the limits of legislation”. In:W. Cornelius; P. Martin;J. Hollifield (orgs.), Controlling immigration: a global perspective. Standford: Standford University Press, 55-82.

CASTLES, Stephen. 1986. “The guest-worker in Western Europe - an obituary”. International Migration Review, 20(4): 761-778. Special Issue: Temporary Worker Programs: mechanisms, conditions, consequences.

CASTLES, Stephen. 2006. “Guestworker in Europe: a ressurection?”. International Migration Review, 40(4): 741-766.

COHEN, Eric. 1973. "Nomads from aflluence: notes on the phenomenon of drifter tourism". International Journal of Comparative Sociology, 14: 89-103. CUNNINGHAM \& HEYMAN. 2004. "Introduction: mobilities and enclosures at borders". Identities: Global Studies in Culture and Power, 11(3): 289-302.

DESFORGES, Luke. 200o. "Travelling the world - identity and travel biography". Annals of Tourism Research, 27(4): 926-945.

DIAS, Guilherme Mansur. 2007. Experiências de trabalho temporário nos Estados Unidos: uma abordagem etnográfica do Okemo. Dissertação de Mestrado em Antropologia Social, PPGAS, Universidade Estadual de Campinas Campinas.

FANTASIA, Rick. 2003. "Despotismo no trabalho e dessindicalização”. In: Lins \&Wacquant (orgs.), Repensar os Estados Unidos: por uma sociologia do superpoder. Campinas: Papirus. 256p.

FELDMAN-BIANCO, Bela. 2001a. "Brazilians in Portugal, Portuguese in Brazil: cultural constructions of sameness and difference”. Identities: Global Studies in Culture and Power, 8: 607-650.

FELDMAN-BIANCO, Bela. 2001b. "Colonialism as a continuing project: the Portuguese experience" Identities: Global Studies in Culture and Power, 8: 477-482.

GAMBOA, Erasmo. 1987. "Braceros in thepacificnorthwest: laborers in thedomestic front: 1942-1947". Pacific HistoricalReview, 53(3): 378-398. GEERTZ, Clifford. 1973. "Uma descrição densa: por uma teoria interpretativa da cultura”. In: A interpretação das culturas. Rio de Janeiro: Zahar Editores S.A. 323pp. 
GRASMUCK \& PESSAR. 1991. Between two islands: dominican international migration. Berkeley: University of California Press.

GRIFFITH, David. 2006. American guestworkers: jamaicans and mexicans in the U.S. labor market. University Park, PA: Pennsylvania State University Press, 256pp.

HAHAMOVITCH, Cindy. 2003. "Creating perfect immigrants: guestworkers of the world". Historical PerspectiveinLabor History, 44(1): 69-94.

HOUSTON, M. F. \& MARTIN, P. L. 1979.“The future of international labor migration”.JournalofInternationalAffairs, 33(2): 311.

LÉVI-STRAUSS, Claude. 1996. Tristes trópicos. São Paulo: Companhia das Letras.

LÓPEZ-RUIZ, Osvaldo Javier. 2004. O ethos dos executivos das transnacionais e o espírito do capitalismo. Tese de doutorado, IFCH/UNICAMP, Campinas.

LORENTZ, Karen. 1996. Okemo: all come home. Montpelier: S/Ed.

MACHADO, Igor J. 1997. Dias em Movimento: espaço e poder numa "comunidadedormitório" mineira. Dissertação de Mestrado em Antropologia Social, PPGAS, Universidade Estadual de Campinas, Campinas.

MACHADO, Igor J. 2003. Cárcere público: processos de exotização entre imigrantes brasileiros no Porto, Portugal. Tese de Doutorado em Ciências Sociais, Programa de Pós Graduação em Ciências Sociais, Universidade Estadual de Campinas, Campinas.

MARTIN, Philip L. 1998. “Guestworkers: past and present”. In: Factors that influence migration:the binational study: migration between Mexico and the US. Austin: Texas University. 877-895.

MARTIN, Philip L. 2003. Managing labor migration: temporary worker programs for the 21st Century. Geneva: September.

MILLER, Mark. 1986. “Introduction”. International Migration Review, 20(4): 740-757. Special Issue: Temporary Worker Programs: mechanisms, conditions, consequences.

MINTZ, Sidney. 1996. "Enduring substances, trying theories: the Caribbean region as oikumene" Journal of Royal Anthropological Institute, 2: 289-313.

MUNT, Ian. 1994. “The 'other' postmodern tourism: culture, travel and the new middle classes". Theory, Culture and Society, 11: 101-123.

PEIRANO, Mariza. 2009. "O paradoxos dos documentos de identidade: relato de uma experiência nos Estados Unidos”. Horizontes Antropológicos, 32: $53-80$. 
REUBENS, Edwin P. 1986. “Temporary Foreign Workers in the U.S.: myths, facts and policies". International Migration Review, 20(4): 1037-1047.

RIBEIRO, Gustavo L. 1997. “A corrida por paisagens autênticas: turismo, meio ambiente e subjetividade no mundo contemporâneo". In: C. Serrano \& H. Bruhns (orgs.), Viagens à natureza: turismo, cultura e ambiente. Campinas: Papirus. 27-42.

RUHS, Martin. 2001. "Labor immigration programmes in Germany, 1950200o". International Labor Organization (ILO).Geneva. Mimeo.

RUHS, Martin. 2002. “Temporary foreign worker programmes: policies, adverse consequences, and the need to make them work". International Labor Ornganization (ILO).Geneva. Mimeo.

RUHS, Martin. 2005. "The potential of temporary migration programmes in future international migration policy”. Global Commission on International Migration. Geneva, September. Mimeo.

SANJURJO, Liliana L. 2007. Narrativas do exilio argentino no Brasil: nação, memórias e identidades. Dissertação de Mestrado em Antropologia Social, PPGAS, Universidade Estadual de Campinas, Campinas.

SANTOS, Gustavo Adolfo P. 2002. Lideranças imigrantes e o Estado Português. Ações e contradições de uma Aliança Lusófona Portugal (1990-2002).

Dissertação de Mestrado em Antropologia Social, PPGAS, Universidade Estadual de Campinas, Campinas.

SILVA, Douglas M. 2000. A ética da resistência: os exilados antisalazaristas do 'Portugal Democrático'(1956-1975). Dissertação de Mestrado em Antropologia Social, Unicamp, Campinas. 